\title{
Hemorrhagic choroidal detachment after use of anti-glaucomatous eye drops: case report
}

\author{
Descolamento hemorrágico de coroide após o uso de colírios antiglaucomatosos: relato de caso
}

\author{
Deniz Turgut Coban ${ }^{1}$, Muhammet Kazim Erol ${ }^{1}$, Ozgur Yucel $^{1}$
}

\begin{abstract}
Eighty-two-year-old patient with a pacemaker using warfarin due to arrhythmia and having an intraocular lens in the right eye, developed spontaneous hemorrhagic choroidal detachment one day after the use of combined preparation of $0.5 \%$ timolol maleate and $0.004 \%$ travoprost, due to primary open-angle glaucoma. Hemorrhagic detachment was detected by anterior and posterior segment examination, as well as B-scan ultrasonography. After the detachment, excessive increased intraocular pressure was controlled with oral carbonic anhydrase inhibitor, cycloplegic and steroid therapy. After four months, visual acuity was $20 / 20$ and the intraocular pressure was under control with $0.5 \%$ timolol maleate and $1 \%$ brinzolamide. Controlled reduction of the intraocular pressure should be considered, particularly in older patients under anticoagulant therapy and that had undergone prior ocular surgery.
\end{abstract}

Keywords: Choroid hemorrhage/chemically induced; Choroid hemorrhage/ diagnosis; Antihypertensive agents/adverse effects; Antihypertensive agents/ administration \& dosage; Case report

\begin{abstract}
RESUMO
Paciente de oitenta e dois anos de idade com marca-passo e utilizando varfarina devido à arritmia cardíaca e com uma lente intraocular no olho direito, desenvolveu descolamento de hemorrágico espontâneo de coroide um dia após o uso de colírio combinado de maleato de timolol a 0,5\% e travoprosta a 0,004\%, devido ao glaucoma de ângulo aberto primário. O descolamento hemorrágico foi detectado por análise do segmento anterior e posterior, bem como ultrassonografia modo B. Após o descolamento, o aumento excessivo da pressão intraocular foi controlado por inibidor da anidrase carbônica via oral, terapia cicloplégica e esteroides. Após quatro meses, a acuidade visual era 20/20 e a pressão intraocular estava sob controle com o maleato de timolol a 0,5\% e brinzolamida a 1\%. A redução controlada da pressão intraocular deve ser considerada, especialmente em pacientes idosos sob terapia anticoagulante e que tinham sido submetidos à cirurgia ocular prévia.
\end{abstract}

Descritores: Hemorragia da coróide/induzido quimicamente; Hemorragia da coroide/ diagnóstico; Anti-hipertensivos/efeitos adversos; Anti-hipertensivos/administração \& dosagem; Relato de caso

\section{INTRODUCTION}

Expulsive suprachoroidal hemorrhage is rare and usually occurs secondary to intraocular surgery. Patients older than 65 years, using anticoagulants, history of stroke, gastrointestinal bleeding, recent myocardial infarction, renal failure, severe anemia, are under greater risk. It has been reported that suprachoroidal hemorrhagic detachment could be seen in the patients with high myopia, senile macular degeneration, and diabetic retinopathy using oral anticoagulant spontaneously or after photocoagulation ${ }^{(1)}$. It has been reported that bleeding may occur due to forward movement of the iris and the lens in angle-closure glaucoma ${ }^{(2)}$.

We presented a case with hemorrhagic choroidal detachment after use of anti-glaucomatous drop.

\section{CASE REPORT}

Eighty-two-year-old male patient was admitted complaining of eye pain and decreased vision. The patient used cardiac pacemakers and oral warfarin due to arrhythmia. He has undergone uneventful facoemulsification and intracapsular IOL implantation for right eye two years before his admission. Symptoms began one day after the use of combined preparation of $0.5 \%$ timolol maleate and $0.004 \%$ travoprost as a first drug therapy to primary open-angle glaucoma.
Right eye visual acuity was light perception and intraocular pressure was $49 \mathrm{mmHg}$ in the same eye. At biomicroscopy, anterior chamber was narrowed, pupil was immobile, and an intraocular lens was observed. Fundus examination revealed choroid detachment involving the ciliary body. Hemorrhagic detachment was detected with B-scan ultrasonography (Figure 1A). Except for nuclear cataract, the left eye was normal.

Patient's platelet count was within the normal range, prothrombin time (PT) was 30 seconds, and activated partial thromboplastin time (aPTT) was 40.2. International Normalized Ratio (INR) was 2.47. For patients under anticoagulant use, the desired level of INR is between 2-3. Our patient presented the expected level of INR and no additional pathology related with bleeding was observed.

Initially, the increased intraocular pressure was controlled with oral carbonic anhydrase inhibitor, cycloplegic and steroid therapy and remained under control with $0.5 \%$ timolol maleate and $1 \%$ brinzolamide until the most recent visit.

Right eye visual acuity was 20/50 and 20/20 after two and four months, respectively. Except the immobility of the pupil initially observed, all the pathological bleeding had disappeared. B-scan ultrasonography and composite fundus photograph (Figure $1 \mathrm{~b}$ and Figure 2) revealed resolution of the hemorrhagic detachment.
Submitted for publication: April 8, 2013

Accepted for publication: September 29, 2013

Study carried out at Antalya Education and Research Hospital, Antalya, Turkey.

${ }^{1}$ Physician, Antalya Education and Research Hospital, Department of Ophthalmology, Antalya, Turkey.
Funding: No specific financial support was available for this study.

Disclosure of potential conflicts of interest: D.T.Coban, None; M.K.Erol, None; O.Yucel, None. Correspondence address: Deniz Turgut Coban. Antalya Education and Research Hospital, Department of Ophthalmology, Antalya - Turkey - E-mail: turgutcoban@yahoo.com 


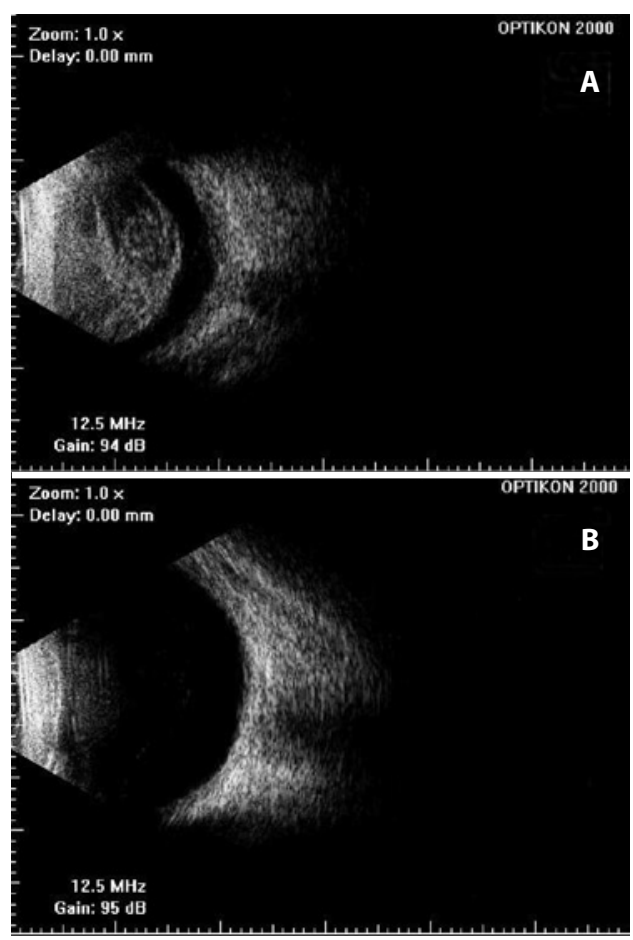

Figure 1.B-Scan utrasonography demonstrating the suprachoroidal hemorrhagic detachment observed at the initial appointment (A), and its resolution, four months later (B).

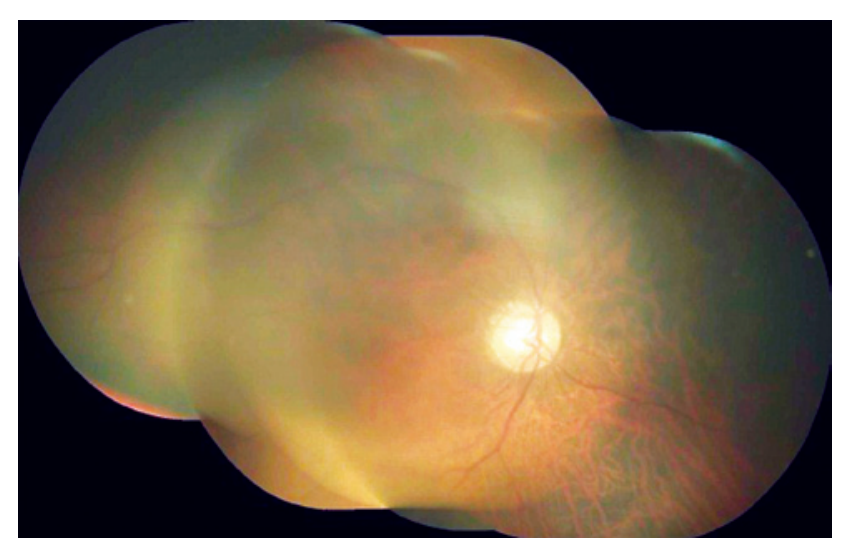

Figure 2. Normal composite fundus photograph four months after initial appointment.

\section{DISCUSSION}

The risk factors of suprachoroidal haemorrhage are: glaucoma, aphakia, increased intraocular pressure, axial myopia, inflammation, age-related macular degeneration and excessive decrease in intraocular pressure(2,3). It has been reported that in myopia due to the fragile choroidal and posterior ciliary vessels, hemorrhage can be more frequent ${ }^{(1)}$. It is expected that the use of drugs that prolong bleeding time would increase the risk of suprachoroidal hemorrhage.

Suprachoroidal hemorrhages have been reported even months after cataract or glaucoma surgery. We considered that in our case, the suprachoroidal hemorrhage, may be related to the sudden decrease in intraocular pressure due to the anti-glaucomatous therapy. It has been reported that choroidal detachment can occur in surgically untreated eyes after use of topical carbonic anhydrase inhibitor ${ }^{(4)}$. In some studies, the use of warfarin was reported as the risk factor for suprachoroidal hemorrhage even months after cataract or glaucoma surgery ${ }^{(5)}$

A satisfactory recovery of visual acuity is not always achieved after medical or surgical treatment of suprachoroidal hemorrhage ${ }^{(3)}$. Some authors emphasized that early diagnosis and the adjustment of anticoagulant therapy have an important role in the medical treatment and control of the eye and systemic disorders ${ }^{(6)}$. In our case, complete recovery was achieved due to early diagnosis and treatment.

Massive spontaneous suprachoroidal hemorrhage is rare. It has been reported in advanced age, mostly in patients taking anticoagulant and according to some publications rarely in the late post-operative period. It should be considered that decrease the intraocular pressure has to be done in a controlled fashion in older patients under oral anticoagulant therapy and that had undergone prior ocular surgery.

\section{REFERENCES}

1. Mikawa A, Honda S, Sugita I, Okamoto N, Toda H. Severe post-laser suprachoroidal haemorrhaging in a diabetic patient receiving anticoagulants. $\mathrm{Br} J$ Ophthalmol. 2004;88(8):1101-2

2. Chu TG, Green RL. Suprachoroidal hemorrhage. Surv Ophthalmol. 1999;43(6):471-86.

3. Manuchehri K, Loo A, Ramchandani M, Kirkby GR. Acute suprachoroidal haemorrhage in a patient treated with streptokinase for myocardial infarction. Eye. 1999;13 (Pt 5):685-6.

4. Goldberg S, Gallily R, Bishara S, Blumenthal EZ. Dorzolamide-induced choroidal detachment in a surgically untreated eye. Am J Ophthalmol. 2004;138(2):285-6.

5. Jeganathan VS, Ghosh S, Ruddle JB, Gupta V, Coote MA, Crowston JG. Risk factors for delayed suprachoroidal haemorrhage following glaucoma surgery. $\mathrm{Br} J$ Ophthalmol. 2008;92(10):1393-6.

6. Chandra A, Barsam A, Hugkulstone C. A spontaneous suprachoroidal haemorrhage: a case report. Cases J. 2009;2:185 